\title{
PHYSICAL ACTIVITY OF PHYSIOTHERAPY STUDENTS AND THE ROLE OF DEVICE-BASED MONITORING IN THEIR FUTURE CLINICAL PRACTICE: A COHORT STUDY
}

\section{AKTYWNOŚĆ FIZYCZNA STUDENTÓW FIZJOTERAPII I ROLA MONITORINGU Z WYKORZYSTANIEM URZĄDZEŃ W ICH PRZYSZŁEJ PRAKTYCE KLINICZNEJ: BADANIE KOHORTOWE}

\author{
Tamara Michalčíková1 ${ }^{1(B, C, D, E, F)}$, Michal Vorlíček ${ }^{2(A, B, D, E, G)}$, Jana Pechová $2(\mathrm{~B}, \mathrm{E}, \mathrm{F})$, \\ Lukáš Jakubec $^{2(C, D, E, F)}$, Karel Frömel ${ }^{2,3(A, B, C, D, E, G)}$, Kateřina Neumannová ${ }^{1(A, B, D, E, G)}$
}

\begin{abstract}
${ }^{1}$ Department of Physiotherapy, Faculty of Physical Culture, Palacký University Olomouc, Czech Republic ${ }^{2}$ Institute of Active Lifestyle, Faculty of Physical Culture, Palacký University Olomouc, Czech Republic ${ }^{3}$ Faculty of Physical Education, the Jerzy Kukuczka Academy of Physical Education, Katowice, Poland
\end{abstract}

Authors' contribution Wkład autorów: A. Study design/planning zaplanowanie badań B. Data collection/entry zebranie danych C. Data analysis/statistics dane - analiza i statystyki D. Data interpretation interpretacja danych E. Preparation of manuscript przygotowanie artykułu F. Literature analysis/search wyszukiwanie i analiza literatury G. Funds collection zebranie funduszy
Summary

Background. Although physiotherapy students are expected to promote and prescribe exercise, their own physical activity (PA) levels have not been fully researched using wearable devices to provide objective measurements of PA. This study aimed (1) to determine their PA level; and (2) to verify the use of wearables for physiotherapy students' own practical benefits. Material and methods. Students $(n=257)$ wore a pedometer (Yamax Digi-Walker SW-700) and wrist-based activity tracker (Garmin Vívofit 1) for seven consecutive days. Prior to monitoring, they completed the long form of the International Physical Activity Questionnaire (IPAQ-LF). A further evaluation was completed, relating to benefits and shortcomings of PA monitoring in their own practice. Results. A significant difference emerged between PA levels recorded with activity trackers on weekdays and weekend days, but only when gender and years of study were not taken into consideration. Specifically, $61.09 \%$ of participants were active or highly active on weekdays and none were sedentary. On the weekend, however, $47.47 \%$ were active or highly active and $11.67 \%$ were sedentary. Most ( 79\%) subjects reported clear benefits in PA monitoring. Conclusions. The student cohort were clearly active during the week, but almost half were insufficiently active in the weekend and thus, greater focus on the promotion of PA in physiotherapists-in-training might be necessary. The self-monitoring of PA under ambulatory conditions (using two wearable devices), combined with self-evaluation of PA, were study strengths.

Keywords: activity trackers, physical activity, physiotherapy, self-evaluation, self-examination, students

\section{Streszczenie}

Wprowadzenie. Chociaż oczekuje się, że studenci fizjoterapii będa promować i zalecać ćwiczenia innym, poziom ich własnej aktywności fizycznej (AF), szczególnie w odniesieniu do pomiarów dokonywanych za pomocą urządzeń, nie został dokładnie zbadany. Celem badania było (1) określenie poziomu aktywności fizycznej oraz (2) zweryfikowanie i wskazanie korzyści zastosowania narzędzi w praktyce studentów fizjoterapii. Materiał i metody. Studenci $(\mathrm{n}=257)$ nosili krokomierz (Yamax Digi-Walker SW-700) oraz opaskę na nadgarstku monitorującą aktywność (Garmin Vívofit 1) przez siedem kolejnych dni. Przed rozpoczeciem pomiaru wypełnili długą wersję Międzynarodowego Kwestionariusza Aktywności Fizycznej (IPAQ-LF). Dodatkowo dokonano oceny zalet i wad kontroli aktywności fizycznej w ich przyszłej praktyce. Wyniki. Jedynie po wykluczeniu płci i roku studiów zaobserwowano znacząca różnicę miedzy poziomami aktywności w dni robocze i w weekendy. Wyniki wykazały, że 61,09\% uczestników badania było aktywnych bądź bardzo aktywnych, a żaden z nich nie prowadził spoczynkowego trybu w dni powszednie. W weekendy z kolei aktywnych bądź bardzo akty wnych uczestników było 47,47\%, a 11,67\% utrzymywało spoczynkowy poziom aktywności. Niemal 79\% badanych zauważyło zalety monitorowania aktywności fizycznej. Wnioski. Badana grupa studentów była niewątpliwie aktywna w dni robocze, ale prawie połowa studentów była aktywna w stopniu niewystarczajacym w weekendy, co oznacza, że należałoby przywiazzywać większą wagę do promocji aktywności fizycznej wśród osób przygotowujących się do wykonywania zawodu fizjoterapeuty. Główną zaletą niniejszego badania była samodzielna kontrola i ocena poziomu aktywności fizycznej przez studentów fizjoterapii dokonana za pomocą dwóch różnych typów przenośnych urządzeń elektronicznych.

Słowa kluczowe: narzędzia pomiaru aktywności, aktywnośćfizyczna, fizjoterapia, samoocena, samokontrola, studenci

Tables: 5

Figures: 2

References: 42

Submitted: 2020 Feb 12

Accepted: 2020 Apr 1

Michalč́ková T, Vorlíček M, Pechová J, Jakubec L, Frömel K, Neumannová K. Physical activity of physiotherapy students and the role of device-based monitoring in their future clinical practice: a cohort study. Health Prob Civil. 2020; 14(2): 107-117. https://doi.org/10.5114/hpc.2020.94271

Address for correspondence / Adres korespondencyjny: Jana Pechová, Institute of Active Lifestyle, Faculty of Physical Culture, Palacký University Olomouc,

Kř́ŕžkovského 511/8, 77900 Olomouc, Czech Republic, e-mail: jana.pechova@upol.cz, phone: +420 585 631 111,
ORCID: Tamara Michalč́lková https://orcid.org/0000-0002-9143-9523, Michal Vorlícek https://orcid.org/0000-0002-8317-9266,

ORCID: Tamara Michalčíková https://orcid.org/0000-0002-9143-9523, Michal Vorlíček https://orcid.org/0000-0002

Karel Frömel https://orcid.org/0000-0001-7848-3418, Kateřina Neumannová https://orcid.org/0000-0003-3097-0852

Copyright: @ Pope John Paul II State School of Higher Education in Biała Podlaska, Tamara Michalčíková, Michal Vorlíček, Jana Pechová, Lukáš Jakubec, Karel Frömel, Kateřina Neumannová. This is an Open Access journal, all articles are distributed under the terms of the Creative Commons Attribution-NonCommercial-ShareAlike 4.0 International (CC BY-NC-SA 4.0) License (http://creativecommons.org/licenses/by-nc-sa/4.0/), allowing third parties to copy and redistribute the material in any medium or format and to remix, transform, and build upon the material, provided the original work is properly cited and states its license. 


\section{Introduction}

There are health and societal concerns regarding a decline in physical activity (PA), coupled with increasing sedentary behaviors, amongst the general population [1-6]. The role of physiotherapists in promoting PA was outlined during the third Physical Therapy Summit on Global Health [7]. Physiotherapists, as healthcare professionals (HCPs), are well placed to promote PA amongst their patients and clients through counseling and activity prescription. To motivate individuals (of any age) to participate regularly in PA, physiotherapists should be physically active themselves, so that they can advise on the benefits of an active lifestyle [8]. Several factors have an immense impact on the PA level of physiotherapy students, for instance, an extensive theoretical class schedule and the need for home study. Individual attitudes towards PA may also be an important indicator of their capability to counsel patients on an active lifestyle. Surprisingly, there is a dearth of quality research describing PA levels among physiotherapists [9]. The deficiency of satisfactory support for physiotherapists to be physically active has also being criticized, likewise the lack of knowledge regarding Physical Activity and Sedentary Behavior guidelines $[10,11]$.

Physiotherapy students should demonstrate profound knowledge of physical activity guidelines, as well as an understanding of the benefits of regular PA. They have other expectations to promote and prescribe individual exercise training to patients with a wide range of diagnoses, concerning musculoskeletal, neurological and civilization diseases as well. Moreover, since physiotherapy students are, upon qualification, responsible for the health education of the general population, it is important to assess their own PA levels and attitudes towards PA that could indirectly enhance (or inhibit) their professional work.

Studies tracking PA among physiotherapy students, in an ordinary day or week, are limited by several methodological factors. For example, some investigated weekday PA levels using self-report methods that are prone to recall error $[8,12-16]$. Based on these subjective evaluations, the physiotherapy students in these studies were mostly classified as being very active. However, only Mahony et al. [15] and Dąbrowska-Galas, Plinta, Dąbrowska, and Skrzypulec-Plinta [12] assessed different levels of PA in physiotherapy students. To our knowledge, only one study investigating PA in students from different health professions, including physiotherapy, uses wearable sensors [17] to provide objective information on type and amount of PA. As a further benefit, wearable devices allow monitoring under ambulatory conditions to track both planned exercise and daily living activities (e.g. walking to work, mowing the lawn). Given this dearth of research, a more detailed analysis of PA habits amongst physiotherapy students, using wearable sensors, is warranted.

Consequently, the aims of the study were to determine physiotherapy students' PA levels over the course of a week and to verify PA monitoring options for their own practical benefit. Furthermore, the study aimed to discover physiotherapy students' subjective attitudes to PA monitoring, as well as to the use of wearable devices in their clinical practice in the future. The results of this study might be used to enhance the quality of physiotherapists' professional preparation and may also assist in facilitating the effective transfer of theoretical knowledge at school, as well as in their professional practice in the future.

\section{Material and methods}

\section{Study design}

This was a cohort study, conducted between 2011 and 2018, on physiotherapy students enrolled in the first year Bachelor's and Master's degree programs. Data were collected once annually, during the fall semester, using a combination of pedometers, activity trackers (from 2016 onwards) and the International Physical Activity Questionnaire - long form (IPAQ-LF). This research formed part of the curriculum, with regular classes to improve their use and understanding of PA monitoring. The students had an opportunity to learn how to use the devices outlined, by self-monitoring their own activities, thereby enabling them to evaluate their practical utility. When participants were introduced to these tools, they were asked to register on the INDARES web application (www.indares.com) and to complete a questionnaire on their weekly PA on the day of the class. A seven-day monitoring period, using pedometers and activity trackers, was launched the following day. Participants also received instructions to complete a prepared paper-based form to record the number of steps per day. The ethical standards of this research were fully in accordance with the Code of Ethics of the Palacký University in Olomouc, Czech Republic. The analysis and publication of study data received ethical approval from the Ethics Committee of the Faculty of Physical Culture (number 24/2012). 


\section{Participants}

The research sample consisted of all the physiotherapy students enrolled in the first year of Bachelor's and Master's degree programs, for a total of 257 participants. Students attending the classes on a regular university day agreed to participate in this study. Each participant was required to sign a consent form before study commencement. Participant anonymity was assured by using code numbers. The students provided sociodemographic information (e.g., age, gender, weight, height, and year of study) once registered for this study.

\section{Procedures}

The participants were asked to wear the pedometer and activity tracker for seven consecutive days and to complete the IPAQ-LF. The Yamax Digi-Walker SW-700 pedometer (Yamax Co., Yasama Corp., Tokyo, Japan) and Garmin Vívofit 1 activity tracker (Garmin, Schaffhausen, Switzerland) were used for weekly habitual PA monitoring. The Yamax device is a hip-worn pedometer that counts steps using a small pendulum, which opens/closes an electric circuit with each movement of the hip [18]. This device has been proven to be suitable for monitoring weekly habitual PA [19]. The wrist-worn activity tracker was introduced later (in 2016), as a reliable and valid method for assessing PA. This device recorded data using a 3-axis accelerometer, which was subsequently processed using an algorithm based on user characteristics, such as height, weight, and age [20]. The activity tracker and pedometer could be considered equivalent in terms of monitoring daily step count [21].

The pedometer was worn on the right hip and the Garmin on the non-dominant wrist. Participants were instructed to wear these devices throughout the day. The devices could be removed for water activities, personal hygiene, and clothing changes. If both devices were worn simultaneously (from 2016) and one was removed, the other device was to be removed as well. To limit the impact of PA reactivity, participants were asked to begin wearing the devices during the introductory session, but actual monitoring began on the following day. Participants completed the daily log with the relevant times and step counts at the following points: putting the device on, arriving at and departing from school, participating in organized PA, and removing the device before going to bed. Participants entered the daily step count from the pedometers into the INDARES web application at the end of the monitoring period. Additionally, prior to returning their devices and daily logs, they provided brief written feedback around perceived benefits and drawbacks from using activity trackers in clinical physiotherapy practice.

According to Mahony et al. [15], the IPAQ has the potential to provide information about health-promoting strategies among healthcare professionals. The IPAQ-LF provides more comprehensive information about different domains of PA, while the IPAQ-short form was developed for surveillance studies with less information provided. In this work, we used the IPAQ-LF to detail the composition of weekly PA in our cohort prior to monitoring. We used the Czech version of the IPAQ-LF questionnaire, which was translated according to the 'EORTC Quality of Life Group' [22] and empirically verified in international comparative studies [23, 24]. Participants estimated the structure of their PA in their jobs, at school, in transportation (walking, cycling), at home (housekeeping and family care), as well as during recreation, and time spent sitting.

\section{Data processing and analysis}

The IPAQ-LF data were processed in compliance with the IPAQ scoring protocol. The Metabolic Equivalent of Task minute (MET-min) of vigorous PA was multiplied by six, as opposed to a multiplication factor of eight in the original scoring protocol, such that the total PA time could not exceed 600 minutes per day. The maximum level per week was set to 20000 MET-min.

In line with the recommendations for weekly PA presented by Healthy People 2010 [25], Healthy People 2020 [26], the Physical Activity Guidelines for Americans [27], and the EU Physical Activity Guidelines [28], we set the minimum recommendation for weekly PA according to the IPAQ-LF as follows: a minimum of 60 minutes of moderate PA on at least five days a week and, additionally, at least 20 minutes of vigorous PA on three or more days a week ( 5 × 60 minutes of MVPA per week $+3 \times 20$ minutes of VPA per week).

To derive results on the number of steps, we used the classification from Tudor-Locke and Bassett [29]: "sedentary" (<5000 steps/day), "low active" (5000-7499 steps/day), "somewhat active" (7500-9999 steps/day), "active" (10000-12499 steps/day) and "highly active" ( $\geq 12500$ steps/day). The extreme values of pedometerderived data were adjusted in line with previous studies. Data for any single day indicating $<1000$ steps were removed and values of $>30000$ steps on any single day were truncated to 30000 steps [30]. 
The brief written feedback provided by the participants focusing on the pros and cons of using activity trackers was coded (pros as number 1, cons as number 2) and evaluated by one of the research investigators. Only those pros and cons mentioned in the form by at least three students were taken into consideration.

\section{Statistical analyses}

The Statistica 13 program (StatSoft Inc., Prague, Czech Republic) was used for statistical testing. We applied the following statistical methods to check and process our dataset: crossing tables to evaluate the number and percentage of participants in different groups per daily PA levels, Kruskal-Wallis analysis of variance (ANOVA) to determine differences in PA levels between male and female students and years of study, and a repeatedmeasures ANOVA with an unequal sample size to determine differences in steps/days in particular days of a week by gender and years of study. Where appropriate, the HSD post-hoc test was applied. Effect size coefficients $\left(\eta^{2}\right.$, $\eta_{p}{ }^{2}$, and $r$ ) were also calculated: $\eta^{2}-0.01-0.059$ small, 0.06-0.139 medium and $\geq 0.14$ large effect size; $\eta_{p}{ }^{2}: 0.1-0.29$ small, 0.3-0.49 medium and $\geq 0.5$ large effect size; $r(0.1 \leq r<0.2$ small; $0.2 \leq r<0.6$ medium; and $r \geq 0.6$ large effect size). Statistical significance was set at the level of $p<0.05$.

\section{Results}

All participants were similar in terms of age and BMI, according to gender and the specific year of study. The sample characteristics and mean number of steps for each sub-group are provided in Table 1.

Table 1. Sample characteristics

\begin{tabular}{|c|c|c|c|c|c|c|c|c|c|c|c|}
\hline \multirow{2}{*}{ Gender/Year of study } & \multirow{2}{*}{$\boldsymbol{n}$} & \multicolumn{2}{|c|}{$\begin{array}{c}\text { Age } \\
\text { (years) }\end{array}$} & \multicolumn{2}{c|}{$\begin{array}{c}\text { Weight } \\
\text { (kg) }\end{array}$} & \multicolumn{2}{c|}{$\begin{array}{c}\text { Height } \\
\text { (cm) }\end{array}$} & \multicolumn{2}{c|}{$\begin{array}{c}\text { BMI } \\
\left(\mathbf{k g}^{-2} \text { ) }\right.\end{array}$} & \multicolumn{2}{c|}{$\begin{array}{c}\text { Steps/day } \\
\text { (number) }\end{array}$} \\
\cline { 3 - 11 } & & $\boldsymbol{M}$ & $\boldsymbol{S D}$ & $\boldsymbol{M}$ & $\boldsymbol{S D}$ & $\boldsymbol{M}$ & $\boldsymbol{S D}$ & $\boldsymbol{M}$ & $\boldsymbol{S D}$ & $\boldsymbol{M}$ & $\boldsymbol{S D}$ \\
\hline Males & 63 & 21.04 & 1.91 & 76.92 & 7.98 & 182.02 & 5.61 & 23.20 & 1.93 & 10821 & 2910 \\
\hline Females & 194 & 21.22 & 2.01 & 60.81 & 7.29 & 168.24 & 6.43 & 21.48 & 2.16 & 10778 & 2821 \\
\hline $\begin{array}{c}\text { Males 1st year } \\
\text { Bachelor's }\end{array}$ & 37 & 20.37 & 1.24 & 75.92 & 7.66 & 181.57 & 5.94 & 23.01 & 1.87 & 10997 & 2786 \\
\hline Males 1st year Master's & 26 & 22.00 & 2.29 & 78.35 & 8.34 & 182.65 & 5.14 & 23.46 & 2.02 & 10569 & 3117 \\
\hline $\begin{array}{c}\text { Females 1st year } \\
\text { Bachelor's }\end{array}$ & 74 & 20.14 & 0.86 & 60.84 & 6.65 & 168.46 & 6.40 & 21.44 & 2.06 & 10926 & 3114 \\
\hline $\begin{array}{c}\text { Females 1st year } \\
\text { Master's }\end{array}$ & 120 & 21.88 & 2.22 & 60.80 & 7.69 & 168.11 & 6.47 & 21.49 & 2.22 & 10687 & 2634 \\
\hline
\end{tabular}

Note: $n=$ number; $M=$ mean; $S D=$ standard deviation; BMI = Body Mass Index.

During the weekend days, $11.67 \%$ of participants were sedentary and only $47.47 \%$ of them were active or highly active. On weekdays, no participants were sedentary and $61.09 \%$ of the students were active or highly active. The mean values were $11020 \pm 2909$ steps/day on weekdays and $10211 \pm 4669$ steps/day on weekend days $\left(F(1.253)=6.86 ; p=.009 ; \eta_{p}^{2}=.026\right)$. Tables 2,3 , and 4 indicate the number and percentage of participants, per level of activity, on each day of the week. The greatest proportion of participants were highly active on Tuesday (41.63\%) and the smallest proportion of participants were highly active on Sunday (23.74\%). The tables also show that, even though participants were less physically active on one day, they compensated for this on other days. Therefore, there was no significant overall difference between activity levels on weekdays and weekend days. A significant difference was found between PA level on weekdays and weekend days, but only when gender and years of study were not taken into consideration.

Table 2. Number and percentage of participants per daily level of physical activity

\begin{tabular}{|c|c|c|c|c|c|c|c|c|c|c|}
\hline \multirow{2}{*}{ Level of activity } & \multicolumn{2}{|c|}{ Sedentary } & \multicolumn{2}{|c|}{ Low active } & \multicolumn{2}{c|}{$\begin{array}{c}\text { Somewhat } \\
\text { active }\end{array}$} & \multicolumn{3}{|c|}{ Active } & \multicolumn{2}{|c|}{ Highly active } \\
\hline Days & $\boldsymbol{n}$ & {$[\%]$} & $\boldsymbol{n}$ & {$[\%]$} & $\boldsymbol{n}$ & {$[\%]$} & $\boldsymbol{n}$ & {$[\%]$} & $\boldsymbol{n}$ & {$[\%]$} \\
\hline Monday & 21 & 8.17 & 37 & 14.39 & 69 & 26.85 & 60 & 23.35 & 70 & 27.24 \\
\hline Tuesday & 7 & 2.72 & 27 & 10.51 & 52 & 20.24 & 64 & 24.90 & 107 & 41.63 \\
\hline Wednesday & 20 & 7.78 & 67 & 26.07 & 48 & 18.68 & 47 & 18.29 & 75 & 29.18 \\
\hline Thursday & 16 & 6.23 & 45 & 17.51 & 74 & 28.79 & 55 & 21.40 & 67 & 26.07 \\
\hline Friday & 19 & 7.40 & 46 & 17.90 & 46 & 17.90 & 51 & 19.84 & 95 & 36.96 \\
\hline
\end{tabular}




\begin{tabular}{|c|c|c|c|c|c|c|c|c|c|c|}
\hline Saturday & 48 & 18.68 & 41 & 15.95 & 36 & 14.02 & 39 & 15.16 & 93 & 36.19 \\
\hline Sunday & 40 & 15.56 & 60 & 23.34 & 57 & 22.18 & 39 & 15.18 & 61 & 23.74 \\
\hline Weekdays & 0 & 0 & 23 & 8.95 & 77 & 29.96 & 87 & 33.85 & 70 & 27.24 \\
\hline Weekend days & 30 & 11.67 & 42 & 16.34 & 63 & 24.52 & 53 & 20.62 & 69 & 26.85 \\
\hline
\end{tabular}

Note: sedentary = <5000 steps/day; low active = 5000-7499 steps/day; somewhat active = 7500-9999 steps/day; active = 10000-12499 steps/day; highly active $=\geq 12500$ steps/day.

Table 3. Number and percentage of male participants per daily level of physical activity

\begin{tabular}{|c|c|c|c|c|c|c|c|c|c|c|}
\hline \multirow{2}{*}{ Level of activity } & \multicolumn{2}{|c|}{ Sedentary } & \multicolumn{2}{|c|}{ Low active } & \multicolumn{2}{c|}{$\begin{array}{c}\text { Somewhat } \\
\text { active }\end{array}$} & \multicolumn{3}{|c|}{ Active } & \multicolumn{2}{|c|}{ Highly active } \\
\hline Days & $\boldsymbol{n}$ & {$[\%]$} & $\boldsymbol{n}$ & {$[\%]$} & $\boldsymbol{n}$ & {$[\%]$} & $\boldsymbol{n}$ & {$[\%]$} & $\boldsymbol{n}$ & {$[\%]$} \\
\hline Monday & 4 & 6.35 & 9 & 14.29 & 21 & 33.33 & 16 & 25.40 & 13 & 20.63 \\
\hline Tuesday & 2 & 3.17 & 8 & 12.70 & 8 & 12.70 & 11 & 17.46 & 34 & 53.97 \\
\hline Wednesday & 8 & 12.70 & 18 & 28.57 & 7 & 11.11 & 14 & 22.22 & 16 & 25.40 \\
\hline Thursday & 6 & 9.52 & 12 & 19.05 & 19 & 30.16 & 13 & 20.63 & 13 & 20.63 \\
\hline Friday & 7 & 11.11 & 14 & 22.22 & 8 & 12.70 & 6 & 9.52 & 28 & 44.44 \\
\hline Saturday & 13 & 20.63 & 8 & 12.70 & 8 & 12.70 & 9 & 14.29 & 25 & 39.68 \\
\hline Sunday & 9 & 14.29 & 14 & 22.22 & 16 & 25.40 & 9 & 14.29 & 15 & 23.81 \\
\hline Weekdays & 0 & 0 & 6 & 9.52 & 18 & 28.57 & 23 & 36.51 & 16 & 25.40 \\
\hline Weekend days & 9 & 14.29 & 7 & 11.11 & 16 & 25.40 & 14 & 22.22 & 17 & 26.98 \\
\hline
\end{tabular}

Note: sedentary = <5000 steps/day; low active = 5000-7499 steps/day; somewhat active = 7500 -9999 steps/day; active = 10000-12499 steps/day; highly active $=\geq 12500$ steps/day.

Table 4. Number and percentage of female participants per daily level of physical activity.

\begin{tabular}{|c|c|c|c|c|c|c|c|c|c|c|}
\hline Level of activity & \multicolumn{2}{|c|}{ Sedentary } & \multicolumn{2}{c|}{ Low active } & \multicolumn{2}{c|}{$\begin{array}{c}\text { Somewhat } \\
\text { active }\end{array}$} & \multicolumn{3}{|c|}{ Active } & \multicolumn{2}{|c|}{ Highly active } \\
\hline Days & $\boldsymbol{n}$ & {$[\%]$} & $\boldsymbol{n}$ & {$[\%]$} & $\boldsymbol{n}$ & {$[\%]$} & $\boldsymbol{n}$ & {$[\%]$} & $\boldsymbol{n}$ & {$[\%]$} \\
\hline Monday & 17 & 8.76 & 28 & 14.43 & 48 & 24.74 & 44 & 22.68 & 57 & 29.38 \\
\hline Tuesday & 5 & 2.58 & 19 & 9.79 & 44 & 22.68 & 53 & 27.32 & 73 & 37.63 \\
\hline Wednesday & 12 & 6.19 & 49 & 25.26 & 41 & 21.13 & 33 & 17.01 & 59 & 30.41 \\
\hline Thursday & 10 & 5.15 & 33 & 17.01 & 55 & 28.35 & 42 & 21.65 & 54 & 27.84 \\
\hline Friday & 12 & 6.19 & 32 & 16.49 & 38 & 19.59 & 45 & 23.20 & 67 & 34.54 \\
\hline Saturday & 35 & 18.04 & 33 & 17.01 & 28 & 14.43 & 30 & 15.46 & 68 & 35.05 \\
\hline Sunday & 31 & 15.98 & 46 & 23.71 & 41 & 21.13 & 30 & 15.46 & 46 & 23.71 \\
\hline Weekdays & 0 & 0 & 17 & 8.76 & 59 & 30.41 & 64 & 32.99 & 54 & 27.84 \\
\hline Weekend days & 21 & 10.82 & 35 & 18.04 & 47 & 24.23 & 39 & 20.10 & 52 & 26.80 \\
\hline
\end{tabular}

Note: sedentary = <5000 steps/day; low active = 5000-7499 steps/day; somewhat active $=7500-9999$ steps $/$ day; active = 10000-12499 steps/day; highly active $=\geq 12500$ steps/day.

For weekdays separately, we did not find any significant difference between male and female participants in terms of walking, at least based on the recommended 10000 steps per day (Figure 1). This recommendation was most adhered to by males (71.43\%) and females (64.95\%) on Tuesdays, with the lowest adherence on Sundays for both males $(38.10 \%)$ and females $(39.18 \%)$.

We found a significant difference in adherence to the recommendation of 10000 steps/day between years on Tuesdays (first-year bachelor's students: $75.66 \%$ and first-year master's students: $59.59 \%)(p=.007)$ and similarly on Wednesdays (first-year bachelor's students: 54.95\% and first-year master's students: $41.78 \%$ ) $(p=.036)$.

We observed a higher average number of steps on Tuesdays compared to other days, $F(6.1518)=4.11 ; p<.001$; $\eta_{p}{ }^{2}=.016$ (Figure 2). However, when we considered the additional interaction between gender and years (days $\mathrm{x}$ gender $x$ years), we did not find any significant differences, $F(6.1518)=.641 ; p=.697 ; \eta_{p}{ }^{2}=.003$. 


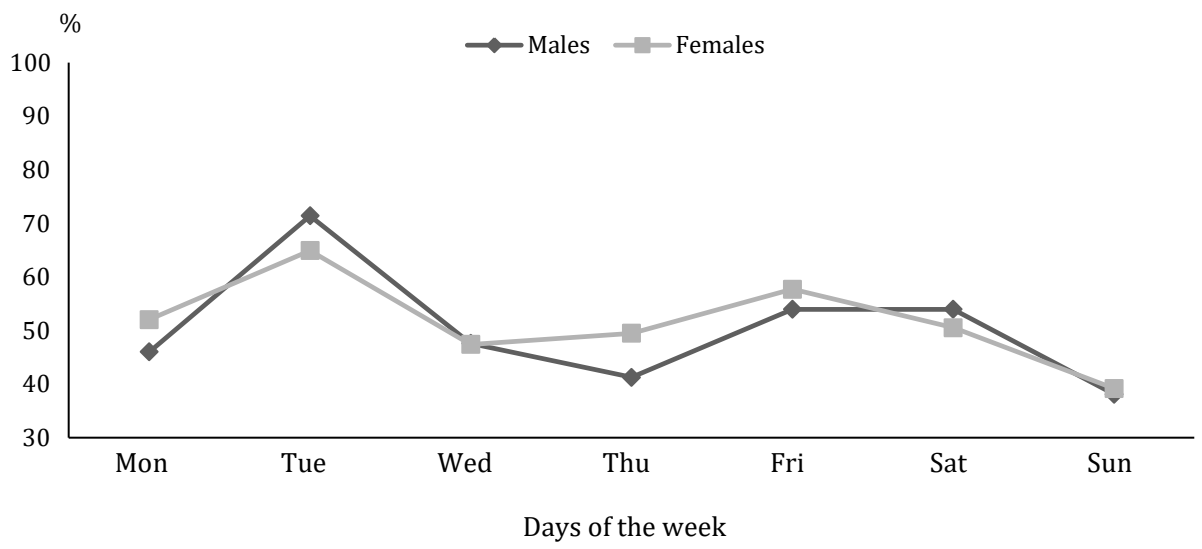

Figure 1. Percentage of males and females who adhered to the recommendation of 10000 steps/day on weekdays

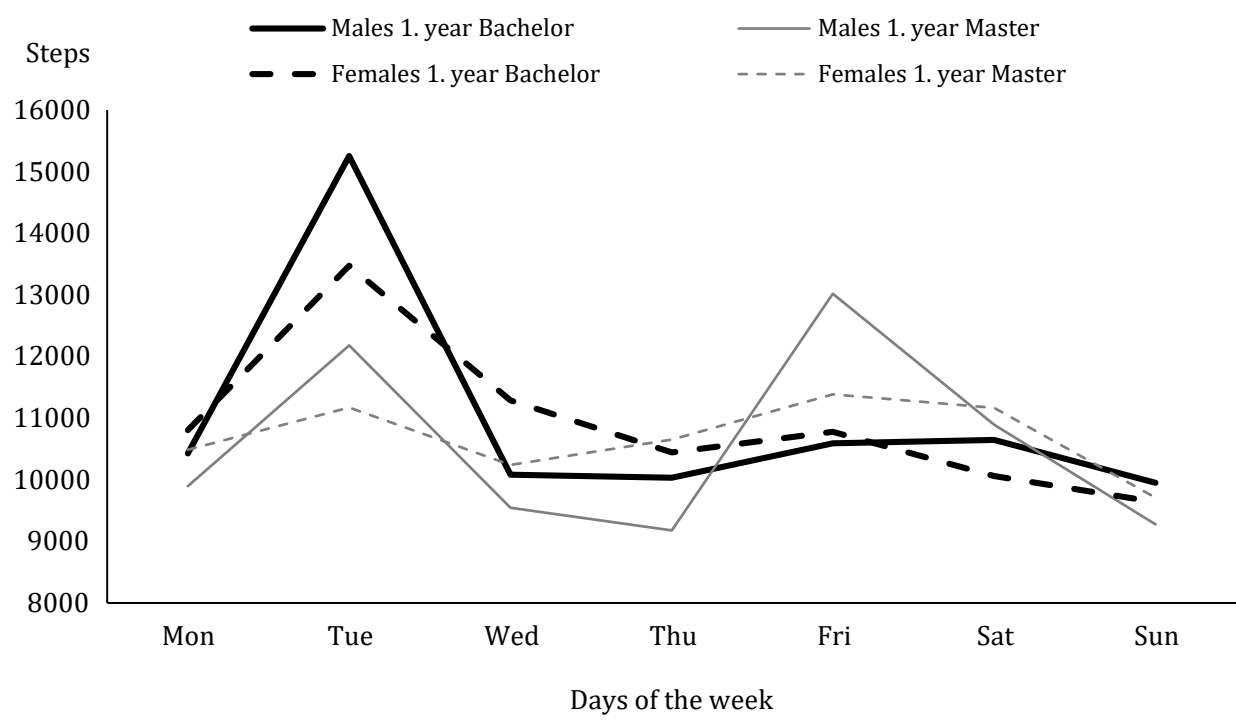

Figure 2. The number of steps per day for males and females on each day of the week per study program

Table 5 outlines estimated PA for a week using the pre-study IPAQ. We did not find any significant differences in whole-week PA levels for either males or females. Statistically significant differences were, however, found between male and female first-year bachelor's students for school PA $(p=0.035)$ and between male and female first-year master's students for vigorous PA $(p=0.008)$. In summary, the IPAQ's stringent recommendation of 60 minutes (minimum) of moderate PA at least five times a week and, additionally, at least 20 minutes of vigorous PA three times a week was adhered to by few males (34.92\%) and females $(18.04 \%)$ in this study $\left(\chi^{2}=7.85\right.$, $p=.007, r=.165$ ).

Table 5. Estimates of a week's physical activity using the IPAQ for males and females per study program

\begin{tabular}{|c|c|c|c|c|c|c|c|}
\hline \multirow{3}{*}{ Physical activity } & \multicolumn{2}{|c|}{ Males } & \multicolumn{2}{|c|}{ Females } & \multirow{3}{*}{$\boldsymbol{H}$} & \multirow{3}{*}{$p$} & \multirow{3}{*}{$\eta^{2}$} \\
\hline & $\begin{array}{c}\text { 1st year } \\
\text { bachelor's } \\
(n=37)\end{array}$ & $\begin{array}{c}\text { 1st year } \\
\text { master's } \\
(n=26)\end{array}$ & $\begin{array}{c}\text { 1st year } \\
\text { bachelor's } \\
(n=74)\end{array}$ & $\begin{array}{c}\text { 1st year } \\
\text { master's } \\
(n=120)\end{array}$ & & & \\
\hline & $\begin{array}{l}M d n \\
(I Q R)\end{array}$ & $\begin{array}{l}M d n \\
(I Q R)\end{array}$ & $\begin{array}{l}\text { Mdn } \\
(I Q R)\end{array}$ & $\begin{array}{l}M d n \\
(I Q R)\end{array}$ & & & \\
\hline $\begin{array}{c}\text { School } \\
\text { (MET-min/week) }\end{array}$ & $\begin{array}{c}594 \\
(1733)\end{array}$ & $\begin{array}{c}978 \\
(2628)\end{array}$ & $\begin{array}{c}288 \\
(1188)\end{array}$ & $\begin{array}{c}720 \\
(1677)\end{array}$ & $8.58^{\mathrm{a}}$ & 0.035 & $0.034^{*}$ \\
\hline $\begin{array}{c}\text { Transport } \\
\text { (MET-min/week) }\end{array}$ & $\begin{array}{c}792 \\
(1287)\end{array}$ & $\begin{array}{c}842 \\
(1320)\end{array}$ & $\begin{array}{c}743 \\
(1040)\end{array}$ & $\begin{array}{c}792 \\
(1221)\end{array}$ & 0.92 & 0.821 & 0.004 \\
\hline $\begin{array}{c}\text { Home } \\
\text { (MET-min/week) }\end{array}$ & $\begin{array}{c}270 \\
(655) \\
\end{array}$ & $\begin{array}{c}205 \\
(745) \\
\end{array}$ & $\begin{array}{c}330 \\
(640)\end{array}$ & $\begin{array}{c}230 \\
(595)\end{array}$ & 1.08 & 0.781 & 0.004 \\
\hline
\end{tabular}




\begin{tabular}{|c|c|c|c|c|c|c|c|}
\hline $\begin{array}{c}\text { Recreation } \\
\text { (MET-min/week) }\end{array}$ & $\begin{array}{c}1314 \\
(1499)\end{array}$ & $\begin{array}{c}1380 \\
(2001)\end{array}$ & $\begin{array}{c}1455 \\
(1376)\end{array}$ & $\begin{array}{c}1269 \\
(1386)\end{array}$ & 5.32 & 0.150 & $0.021^{*}$ \\
\hline $\begin{array}{c}\text { Vigorous } \\
\text { (MET-min/week) }\end{array}$ & $\begin{array}{c}720 \\
(1440)\end{array}$ & $\begin{array}{c}1170 \\
(1980)\end{array}$ & $\begin{array}{c}720 \\
(1200)\end{array}$ & $\begin{array}{c}450 \\
(1440)\end{array}$ & $11.86^{\mathrm{b}}$ & 0.008 & $0.046^{*}$ \\
\hline $\begin{array}{c}\text { Moderate } \\
\text { (MET-min/week) }\end{array}$ & $\begin{array}{c}1135 \\
(1650)\end{array}$ & $\begin{array}{c}1373 \\
(1650)\end{array}$ & $\begin{array}{c}765 \\
(1360)\end{array}$ & $\begin{array}{c}1170 \\
(1726)\end{array}$ & 5.47 & 0.140 & $0.021^{*}$ \\
\hline $\begin{array}{c}\text { Walking } \\
\text { (MET-min/week) }\end{array}$ & $\begin{array}{c}1485 \\
(1782)\end{array}$ & $\begin{array}{c}1535 \\
(1881)\end{array}$ & $\begin{array}{c}1452 \\
(1881)\end{array}$ & $\begin{array}{c}1518 \\
(1766)\end{array}$ & 0.38 & 0.944 & 0.001 \\
\hline $\begin{array}{c}\text { Total } \\
\text { (MET-min/week) }\end{array}$ & $\begin{array}{c}3669 \\
(3684)\end{array}$ & $\begin{array}{c}4638 \\
(4053)\end{array}$ & $\begin{array}{c}3290 \\
(3175)\end{array}$ & $\begin{array}{c}3864 \\
(3485)\end{array}$ & 3.02 & 0.389 & $0.012^{*}$ \\
\hline
\end{tabular}

Note: $n=$ number, $M d n=$ median, $I Q R=$ interquartile, $H=$ Kruskal-Wallis test, $p=$ level of significance, $\eta^{2}=$ effect size coefficient, a / significant difference between the first-year bachelor's males and females, ${ }^{\mathrm{b}} /$ significant difference between the first-year master's males and females, ${ }^{*} / 0.01 \leq \eta^{2}<0.06$ small effect size.

The brief feedback provided by participants yielded important insight on the perceived benefits and shortcomings of PA monitoring. Among the most mentioned benefits was the motivation to increase the amount of PA by walking or engaging in different sporting activities. Overall, $78.60 \%$ of participants derived some benefit from PA monitoring; 19.07\% appreciated the information provided by the pedometer and activity tracker, and liked knowing the number of steps they walked each day. Some participants did complain about the inconvenience associated with preparing a paper-based form for activity monitoring, such as forgetting to write down required information (time, number of steps). Additionally, 9.34\% of participants reported that the activity trackers did not detect certain types of PA, such as cycling or kayaking, and they objected to not being able to wear the activity trackers for swimming. No cons whatsoever were reported by $21.01 \%$ of the participants.

\section{Discussion}

In this cohort study, we investigated the PA composition of an ordinary week among physiotherapy students, using both subjective and objective measures of activity. This study presented a unique opportunity for health professionals in training to utilize and evaluate two different PA monitoring devices (pedometer, activity tracker) that could inform their own practices in the future.

According to data collected from the wearable devices, over half of the students (61.1\%) were active or highly active on the weekdays and no students were classified as inactive on these days. On the contrary, $11.7 \%$ of the students were inactive on the weekend days and only $47.5 \%$ were found to be active or highly active. Congruent findings were obtained from college students of a similar age when using ambulatory measurement devices [5, 31, 32].

Several studies have evaluated the PA habits of university healthcare students, including physiotherapy students, using the IPAQ or other questionnaires [8, 12-16,33]. Physiotherapy students were found to be more active than nursing students $[13,15]$ and medical students [12], but less (although sufficiently) active than nutrition students [14]. Moreover, physiotherapy students showed healthier lifestyle habits (less or no smoking or intake of unhealthy snacks, adequate sleep) than nursing students [13]. Among physiotherapy students, $62 \%$ [16], 88-95\% [33], and 97\% [13] exercised regularly, and 69\% were highly active [14]. In our study, the males were found to be more active than the females, which corresponds with other research findings $[16,17]$.

To the best of our knowledge, only Mahony et al. [15] and Dąbrowska-Galas, Plinta, Dąbrowska, and SkrzypulecPlinta [12] conducted studies on physiotherapy and other healthcare students, based on the subjective evaluation of PA using the IPAQ-short form. Mahony et al. [15]compared students on outcomes of vigorous, moderate and low PA (MET-min/week), and found that $56 \%$ of participants were moderately active, $40 \%$ were highly active, and $4 \%$ were inactive. On average, these physiotherapy students accumulated 3586 MET-min/week, whereas the physiotherapy students in the current study accrued 4560 MET-min/week, suggesting a higher level of physical activity. Nevertheless, in contrast to our study, Mahony et al. [15] did not mention the demands of the class schedule (of students) and they did not compare PA on weekdays to that on weekend days.

Little comparable evidence exists regarding sensor (accelerometer) based measurements of PA. Using this approach, Oyeyemi, Muhammed, Oyeyemi, and Adegoke [17] investigated PA and sedentary behavior among university healthcare students in detail. Physiotherapy students engaged in the greatest proportion of vigorous PA (3 min/day), relative to students from other disciplines (e.g., medical laboratory students, medical students). Specifically, they accumulated $447 \mathrm{~min}, 224 \mathrm{~min}$, and $60 \mathrm{~min}$ of sedentary behavior, light-intensity PA, and moderate-intensity PA, respectively. Overall, the most active and least sedentary group was nursing students. 
To our knowledge, no study has presented data on the number of steps taken, alongside other sensor-derived metrics.

Lack of leisure time is considered to be an important factor negatively influencing the PA levels of many adults [34]. This was also evident in our cohort, whose PA levels were limited by school duties that required them to be sedentary. Even though physiotherapy students generally had demanding theoretical and practical class schedules, the majority of them were highly active on Tuesdays, when the educational schedules included over 3.5 (Bachelor) and 6 hours (Masters) of sedentary classes, respectively. As one explanation, many students attend regular evening (social) programs at university. The study results show that, overall, $71.4 \%$ of male and $65 \%$ of female participants achieved the recommended level of PA, despite those constraints imposed by their academic studies. In contrast to this, the students were least active on Sundays (only 38\% of males and 39.2\% of females achieved recommended PA), even though they did not have school duties. These findings are in line with other research conducted on adolescents and the general public [5, 35]. Felton, Tudor-Locke, and Burkett [35] suggested that the lower levels of PA on Sundays might be due to recovery from typical Saturday-night social activities.

The promotion of health behavior is an important part of the professional practice of physiotherapists. The process starts during childhood in the Czech Republic [36]. There is evidence that physiotherapy students learn best through their own clinical experiences [37]. Consequently, experiencing the assessment of PA themselves is crucial for pre-professional students' preparation, to enable them to reappraise their attitudes toward PA, and to improve their knowledge about its benefits and applications. Importantly, students' own behavior is associated with their attitudes towards health promotion, such that a lack of regular PA on their part may be a barrier to counseling and encouraging others to be physically active [8,10]. This assertion is supported by Ranasinghe et al. [38], who stated that encouragement and support for engagement in sporting activities, obtained from family and educators during childhood, is crucial in physiotherapy students as it may have an impact on their exercise behavior in adulthood.

A sound knowledge of PA recommendations is also associated with a stronger sense of promoting such behaviors in routine clinical practice [11]. Aseries of investigations involving trained physiotherapists highlighted poor general knowledge of PA guidelines in Ireland, the UK, Belgium, and Australia [10, 11, 39, 40]. A study by Clifford [41] for example, conducted among physiotherapy students, showed that only $66 \%$ of students knew the current PA guidelines properly. The students in our study were informed about the PA recommendations, subsequent to the one-week measurement in which they participated, and they received feedback on their own level of PA.

Sanders et al. [42] suggested that using wearable sensors can have a positive impact on, and results in higher compliance with, regular PA that meets recommended guidelines. In this study, the participants described PA monitoring as beneficial and particularly appreciated its informative aspect. A disadvantage of this type of monitoring, as stated by some participants, was the requirement to complete a prepared paper-based form to log their number of steps per day. Nowadays, smartphone apps offer a suitable solution to record such information, including time, intensity of PA, the number of steps taken, and so on. This means of tracking may contribute to greater adherence to a PA regime, which may also reinforce the use of a wearable device to capture such activity. Moreover, it could become a motivational element by providing users with set targets and allowing progression to be tracked.

The major contribution of this study was the self-monitoring and self-evaluation of PA in physiotherapy students. Our findings indicate that participants considered the pedometer and activity tracker to be beneficial tools to assess and promote PA. This may help to support the more frequent use of wearables in clinical practice. Our results also suggest that most participants were sufficiently active on weekdays, but insufficiently active on the weekend. Therefore, a stronger focus on the promotion of PA among physiotherapy students, who represent the next generation of healthcare professionals, is required for those individuals whose overall level of PA is below the recommended weekly guidelines.

\section{Strengths and limitations}

There are several strengths to this study. First, we combined subjective and objective methods to evaluate the level of PA in our cohort, which also allowed us to cross-validate each approach to identify any mis-specified events. Secondly, we evaluated each participant in terms of attitude towards PA, as a key factor determining activity choices. Finally, the use of wearable activity trackers provides a valid, reliable and acceptable method for ambulatory monitoring. Nevertheless, limitations should be noted as well. One being inclusion of participants from only one university and the faculty of sports, which may produce bias in our estimates of PA. As a further 
source of bias, the participants completed this study as part of their educational course requirements. Another limitation resides in our study protocols, whereby the participants could not wear the sensors for all forms of routine daily PA, such as swimming.

\section{Disclosures and acknowledgements}

This study was supported by a research grant from the Czech Science Foundation (No. 17-24378S) "Social Norms Intervention in the prevention of excessive sitting and physical activity promotion among Czech adolescents". The authors report no conflict of interest.

\section{References:}

1. Cliff DP, Hesketh KD, Vella SA, Hinkley T, Tsiros MD, Ridgers ND, et al. Objectively measured sedentary behaviour and health and development in children and adolescents: systematic review and meta-analysis. Obes Rev. 2016; 17: 330-344. https://doi.org/10.1111/obr.12371

2. Hansen BH, Kolle E, Steene-Johannessen J, Dalene KE, Ekelund U, Anderssen SA. Monitoring population levels of physical activity and sedentary time in Norway across the lifespan. Scand J Med Sci Spor. 2018; 29(1): 105112. http://dx.doi.org/10.1111/sms.13314

3. Milanović Z, Pantelić S, Sporiš G, Kostić R, James N. Age-related decrease in physical activity and functional fitness among elderly men and women. Clin Interv Aging. 2013; 8: 549-556.

https://doi.org/10.2147/CIA.S44112

4. Owen N, Healy GN, Matthews CE, Dustan DW. Too much sitting: the population-health science of sedentary behavior. Exerc Sport Sci Rev. 2010; 38(3): 105-113. https://doi.org/10.1097/JES.0b013e3181e373a2

5. Sigmundová D, Chmelík F, Sigmund E, Feltlova D, Frömel K. Physical activity in the lifestyle of Czech university students: meeting health recommendations. Eur J Sport Sci. 2013; 13(6): 744-750.

http://dx.doi.org/10.1080/17461391.2013.776638

6. Van Dyck D, De Bourdeaudhuij I, Deliens T. Can changes in psychosocial factors and residency explain the decrease in physical activity during the transition from high school to college or university?. Int J Behav Med. 2015; 22(2): 178-186. http://dx.doi.org/10.1007/s12529-014-9424-4

7. Dean E, Umerah G, Dornelas de Andrade A, Söderlung A, Skinner M. The third physical therapy summit on global health: health-based competencies. Physiother. 2015; 101(Suppl. 1): e13-e14.

https://doi.org/10.1016/j.physio.2015.03.020

8. Chevan J, Haskvitz EM. Do as I do: Exercise habits of physical therapists, physical therapist sssistants, and student physical therapists. Phys Ther. 2010; 90: 726-734. https://doi.org/10.2522/ptj.20090112

9. Lowe A, Gee M, McLean S, Littlewood C, Lindsay C, Everett S. Physical activity promotion in physiotherapy practice: a systematic scoping review of a decade of literature. Brit J Sport Med. 2016; 52(2): $122-127$. http://dx.doi.org/10.1136/bjsports-2016-096735

10. Freene N, Cools S, Bissett B. Are we missing opportunities? Physiotherapy and physical activity promotion: a cross-sectional survey. BMC Sports Sci. Med. Rehabil. 2017; 9(19): 1-8. http://dx.doi.org/10.1186/s13102-017-0084-y

11. Lowe A, Littlewood C, McLean S, Kilner K. Physiotherapy and physical activity: a cross-sectional survey exploring physical activity promotion, knowledge of physical activity guidelines and the physical activity habits of UK physiotherapists. BMJ Open Sport Exerc Med. 2017; 3(1): 1-7. http://dx.doi.org/10.1136/bmjsem-2017-000290

12. Dąbrowska-Galas M, Plinta R, Dąbrowska J, Skrzypulec-Plinta V. Physical activity in students of the Medical University of Silesia in Poland. Phys Ther. 2013; 93: 384-392. https://doi.org/10.2522/ptj.20120065

13. Kamwendo K, Faresjö T, Gustavsson U, Jansson M. Adherence to healthy lifestyles - a comparison of nursing and physiotherapy students. Adv Physiother. 2000; 2: 63-74.

14. Korn L, Gonen E, Shaked Y, Golan M. Health perceptions, self and body image, physical activity and nutrition among undergraduate students in Israel. PLoS ONE. 2013; 8(3): 1-7. https://doi.org/10.1371/journal.pone.0058543

15. Mahony R, Blake C, Matthews J, O’Donnoghue G, Cunningham C. Physical activity levels and self-determined motivation among future healthcare professionals: utility of the Behavioral Regulation in Exercise Questionnaire (BREQ-2). Physiother. Theory Pract. 2018; 39(9): 884-890.

http://dx.doi.org/10.1080/09593985.2018.1457112

16. Michalak K, Cieślak A, Poziomska-Piątkowska E. Personal exercise behavior and attitudes towards physical 
activity among physiotherapy students. Environ Med. 2015; 18(4): 41-45.

17. Oyeyemi AL, Muhammed S, Oyeyemi AY, Adegoke B. Patterns of objectively assessed physical activity and sedentary time: are Nigerian health professional students complying with public health guidelines? PLoS ONE. 2017; 12(12): e0190124. https://doi.org/10.1371/journal.pone.0190124

18. Crouter SE, Schneider PL, Karabulut M, Bassett DR jr. Validity of 10 electronic pedometers for measuring steps, distance, and energy cost. J Sci Med Sport. 2003; 35: 1455-1460. https://doi.org/10.1249/01.MSS.0000078932.61440.A2

19. Schneider PL, Crouter SE, Bassett DR jr. Pedometer measures of free-living physical activity: comparison of 13 models. Med Sci Sport Exer. 2004; 36(2): 331-335. https://doi.org/10.1249/01.MSS.0000113486.60548.E9

20. Mendoza M, Han M, Meyring-Wösten A, Wilund K, Kotanko P. It's a non-dialysis day... Do you know how your patient is doing? A case for research into interdialytic activity. Blood Purif. 2015; 39(1-3): 74-83. https://doi.org/10.1159/000369430

21. Šimůnek A, Dygrýn J, Jakubec L, Neuls F, Frömel K, Welk GJ. Validity of Garmin Vívo fit 1 and Garmin Vívo fit 3 for school-based physical activity monitoring. Pediatr Exerc Sci. 2019; 31(1): 130-136. http://dx.doi.org/10.1123/pes.2018-0019

22. Cull A, Sprangers M, Bjordal K, Aaronson N, West K, Bottomley A. EORTC quality of life group translation procedure (2nd ed.). Brussels: EORTC Quality of Life Unit; 2002.

23. Frömel K, Kudláček M, Groffik D, Svozil Z, Šimůnek A, Garbaciak W. Promoting healthy lifestyle and wellbeing in adolescents through outdoor physical activity. Int. J. Environ. Res. Public Health. 2017; 14(5): 1-12. http://dx.doi.org/10.3390/ijerph14050533

24. Mitáš J, Sas-Nowosielski K, Groffik D, Frömel K. The safety of the neighborhood environment and physical activity in Czech and Polish adolescents. Int. J. Environ. Res. Public Health. 2018; 15(126): 1-11. https://doi.org/10.3390/ijerph15010126

25. U.S. Department of Health and Human Services, National Center for Health Statistics. Healthy People 2010 Final Review [Internet]. Hyattsville, MD: National Center for Health Statistics; 2012 [cited 2019 Apr 20]. Available from: https://www.cdc.gov/nchs/data/hpdata2010/hp2010_final_review.pdf

26. U.S. Department of Health and Human Services. Healthy People 2020: Topics \& Objectives. Physical activity [Internet]. Rockville, MD: Office of Disease Prevention and Health Promotion [cited 2019 Apr 20]. Available from: https://www.healthypeople.gov/2020/topics-objectives/topic/physical-activity

27. U.S. Department of Health and Human Services. Physical activity guidelines for Americans, 2nd edition [Internet]. Washington: U.S. Department of Health and Human Services; 2018 [cited 2019 Apr 20]. Available from: https://health.gov/paguidelines/second-edition/pdf/Physical_Activity_Guidelines_2nd_edition.pdf

28. Gelius P, Rütten A, Goodwin L, Marin M, Abu-Omar K, Kahlmeier S, et al. Study on the implementation of the European physical activity guidelines [Internet]. Luxemburg: Publication Office of the European Union; 2016 [cited 2019 Aug 12]. Available from: https://eacea.ec.europa.eu/sites/eacea-site/files/study_ implementation_pa_guidelines_2016.pdf. http://dx.doi.org/10.2766/42027

29. Tudor-Locke C, Bassett DRJ. How many steps/day are enough? Preliminary pedometer indices for public health. Sports Med. Alert. 2004; 34(1): 1-8. http://dx.doi.org/10.2165/00007256-200434010-00001

30. Tudor-Locke C, Giles-Corti B, Knuiman M, McCormack G. Tracking of pedometer-determined physical activity in adults who relocate: results from RESIDE. Int J Behav Nutr Phys Act. 2008; 5(39): 1-8. http://dx.doi.org/10.1186/1479-5868-5-39

31. Conroy DE, Elavsky S, Doerksen SE, Maher JP. A daily process analysis of intentions and physical activity in college students. J Sport Exerc Psychol. 2013; 35: 493-502.

32. Frömel K, Kudlacek M, Groffik D, Chmelik F, Jakubec L. Differences in the intensity of physical activity during school days and weekends in Polish and Czech boys and girls. Ann Agr Env Med. 2016; 23(2): 357-360. http://dx.doi.org/10.5604/12321966.1203905

33. Öhman A, Stenlund H, Dahlgren L. Career choice, professional preferences and gender - the case of Swedish physiotherapy students. Adv Physiother. 2001; 3: 94-107. https://doi.org/10.1080/140381901750475348

34. Hoare E, Stavreski B, Jennings GL, Kingwell BA. Exploring motivation and barriers to physical activity among active and inactive Australian adults. Sports. 2017; 5(47): 1-8. http://dx.doi.org/10.3390/sports5030047

35. Felton GM, Tudor-Locke C, Burkett L. Reliability of pedometer-determined free-living physical activity data in college women. Res Q Exercise Sport. 2006; 77: 304-308. http://dx.doi.org/10.1080/02701367.2006.10599364

36. Nash Castro LS, Svastisalee CM, Mendes R, Fontaine O, Breda J. School-based physical activity and good practices in Europe. Health Prob Civil. 2019; 13(1): 9-18. https://doi.org/10.5114/hpc.2018.80226

37. Healey W. Physical therapist student approaches to learning during clinical education experiences: a qualitative study [Abstract]. J Phys Ther Educ. 2008; 22(1): 49-58.

38. Ranasinghe C, Sigera C, Ranasinghe P, Jayawardena R, Ranasinghe ACR, Hills AP, et al. Physical inactivity 
among physiotherapy undergraduates: exploring the knowledge-practice gap. BMC Sports Sci. Med. Rehabil. 2016; 8(39): 1-10. https://doi.org/10.1186/s13102-016-0063-8

39. Barrett EM, Darker CD, Hussey J. Promotion of physical activity in primary care: knowledge and practice of general practitioners and physiotherapists. J Public Health. 2013; 21: 63-69. https://doi.org/10.1007/s10389-012-0512-0

40. Mouton A, Mugnier B, Demoulin C, Cloes M. Physical therapists' knowledge, attitudes, and believes about physical activity: a prerequisite to their role in physical activity promotion. J Phys Ther Educ. 2014; 28: 120-127.

41. Clifford R. Promoting physical activity for health. A survey of knowledge, confidence and role-perception in final-year UK physiotherapy students. Physiother Pract Res. 2018; 39: 53-62. https://doi.org/10.3233/PPR-170106

42. Sanders JP, Loveday A, Pearson N, Edwardson C, Yates T, Biddle SJ, et al. Devices for self-monitoring sedentary time or physical activity: a scoping review. J Med Internet Res. 2016; 18(5): e90.

https://doi.org/10.2196/jmir.5373 